\title{
Growth form defines physiological photoprotective capacity in intertidal benthic diatoms
}

\author{
Alexandre Barnett ${ }^{1}$, Vona Méléder ${ }^{1,2}$, Lander Blommaert ${ }^{1,3}$, Bernard Lepetit ${ }^{1,4}$, \\ Pierre Gaudin ${ }^{1,2,5}$, Wim Vyverman ${ }^{3}$, Koen Sabbe ${ }^{3}$, Christine Dupuy ${ }^{1}$ and Johann Lavaud ${ }^{1}$ \\ ${ }^{1}$ UMR7266 LIENSs 'Littoral, Environnement et Sociétés', CNRS/Université de La Rochelle, Institut du Littoral \\ et de l'Environnement, La Rochelle, France; ${ }^{2}$ UPRES EA 2160 MMS 'Mer, Molécules, Santé', Université de \\ Nantes, Faculté des Sciences et Techniques, Nantes Cedex 3, France and ${ }^{3}$ Laboratory of Protistology and \\ Aquatic Ecology, Department of Biology, Ghent University, Ghent, Belgium
}

\begin{abstract}
In intertidal marine sediments, characterized by rapidly fluctuating and often extreme light conditions, primary production is frequently dominated by diatoms. We performed a comparative analysis of photophysiological traits in 15 marine benthic diatom species belonging to the four major morphological growth forms (epipelon (EPL), motile epipsammon (EPM-M) and non-motile epipsammon (EPM-NM) and tychoplankton (TYCHO)) found in these sediments. Our analyses revealed a clear relationship between growth form and photoprotective capacity, and identified fast regulatory physiological photoprotective traits (that is, non-photochemical quenching (NPQ) and the xanthophyll cycle (XC)) as key traits defining the functional light response of these diatoms. EPMNM and motile EPL showed the highest and lowest NPQ, respectively, with EPM-M showing intermediate values. Like EPL, TYCHO had low NPQ, irrespective of whether they were grown in benthic or planktonic conditions, reflecting an adaptation to a low light environment. Our results thus provide the first experimental evidence for the existence of a trade-off between behavioural (motility) and physiological photoprotective mechanisms (NPQ and the XC) in the four major intertidal benthic diatoms growth forms using unialgal cultures. Remarkably, although motility is restricted to the raphid pennate diatom clade, raphid pennate species, which have adopted a non-motile epipsammic or a tychoplanktonic life style, display the physiological photoprotective response typical of these growth forms. This observation underscores the importance of growth form and not phylogenetic relatedness as the prime determinant shaping the physiological photoprotective capacity of benthic diatoms.
\end{abstract}

The ISME Journal (2015) 9, 32-45; doi:10.1038/ismej.2014.105; published online 8 July 2014

\section{Introduction}

Functional trait-based approaches are increasingly adopted to explain and understand the distribution and diversity of phytoplankton communities (Litchman and Klausmeier, 2008; Barton et al., 2013; Edwards et al., 2013). Various morphological and physiological traits have been shown to define the ecological niches of phytoplankton species, including size, temperature response and resource acquisition and utilization traits. For example, in planktonic diatoms, which have a key role in marine

Correspondence: J Lavaud, Institute for Coastal and Environmental Research, UMR 7266 'LIENSs', CNRS/Université de La Rochelle, Institut du Littoral et de l'Environnement (ILE), 2 rue Olympe de Gouges, 17000 La Rochelle, France.

E-mail: johann.lavaud@univ-lr.fr

${ }^{4}$ Current address: Group of Plant Ecophysiology, Department of Biology, University of Konstanz, Universitätsstraße 10, 78457 Konstanz, Germany.

${ }^{5}$ Current address: UMR6112 'LPGN', CNRS/Université de Nantes, Faculté des Sciences et Techniques, 2 rue de la Houssinière, BP 92208, 44322 Nantes Cedex 3, France.

Received 11 October 2013; revised 23 May 2014; accepted 24 May 2014; published online 8 July 2014 primary production and biogeochemical cycling (Armbrust, 2009), pronounced species-specific differences in photosynthetic architecture and photophysiological strategies have been documented (for example, Dimier et al., 2007; Key et al., 2010; Schwaderer et al., 2011; Wu et al., 2012) and related to their in situ light environment (Strzepek and Harrison, 2004; Lavaud et al., 2007; Dimier et al., 2009; Petrou et al., 2011). A high capacity for physiological photoprotection is generally observed in highly fluctuating light climates and/or under on average high irradiances. This suggests that photoprotective capacity is an adaptive trait that shapes the distribution of planktonic diatoms in the environment (Lavaud et al., 2007; Dimier et al., 2009; Bailleul et al., 2010; Petrou et al., 2011; Lavaud and Lepetit, 2013).

Benthic marine environments, and especially intertidal environments, are characterized by even more changeable and extreme light climates resulting from the interplay of weather conditions, tides, water column turbidity and sediment composition (and hence light penetration) (Admiraal, 1984; Underwood and Kromkamp, 1999; Paterson and 
Hagerthey, 2001). Nevertheless, intertidal sediments rank among the most productive ecosystems on Earth, largely owing to the primary production of highly diverse assemblages of benthic diatoms (Underwood and Kromkamp, 1999). To date, however, little is known about the role of functional traits, and especially photophysiological traits, in shaping the structure, dynamics and function of benthic diatom assemblages. In most studies, diatom functional groups are defined on the basis of morphological growth form (for example, Gottschalk and Kahlert, 2012; Larson and Passy, 2012) and not physiological traits. In addition, photoprotective ability (limited to the measurement of the 'xanthophyll cycle', XC) and its relationship with ecology has only been studied in natural communities with mixed assemblages of functional groups (for example, Jesus et al., 2009; van Leeuwe et al., 2009; Cartaxana et al., 2011).

In temperate seas, intertidal benthic communities are largely dominated by diatoms (Méléder et al., 2007; Ribeiro et al., 2013), which display a high degree of taxonomic, phylogenetic and functional diversity (Kooistra et al., 2007). Several growth forms can be distinguished, which mainly differ in their attachment mode and degree of motility (for a detailed description, see Ribeiro et al., 2013): (1) the epipelon (EPL) comprises larger (usually $>10 \mu \mathrm{m}$ ) motile diatoms, which can move freely in between sediment particles and typically form biofilms ( $c f$. Herlory et al., 2004); (2) the epipsammon (EPM) groups smaller (usually $<10 \mu \mathrm{m}$ ) diatoms, which live in close association with individual sand grains; and (3) the tychoplankton (TYCHO), which is an ill-defined and rather enigmatic group of largely non-motile diatoms, which presumably have an amphibious life style (both sediment and water column) (for example, Sabbe et al., 2010). Within the epipsammic group, non-motile (EPM-NM) species are firmly attached (either stalked or adnate) to sand particles, while motile forms (EPM-M) can move within the sphere of individual sand grains. From a phylogenetic perspective, motile forms (that is, all EPL and EPM-M) exclusively belong to the pennate raphid clade (Kooistra et al., 2007), possessing a raphe allowing motility. Most EPM-NM belongs to the pennate araphid lineage, but also includes some raphid pennates, such as Biremis lucens, which firmly attaches to sand grains (Sabbe et al., 1995). TYCHO includes both centric and pennate raphid forms. Intertidal benthic diatom species, but also growth forms, show distinct distribution patterns in time and space, suggesting pronounced (micro)niche differentiation (Sabbe, 1993; Méléder et al., 2007, Ribeiro et al., 2013). For example, EPM dominates non-cohesive sandy sediments (Méléder et al., 2007), while EPL dominates cohesive muddy sediments (Haubois et al., 2005). EPL typically display vertical 'micromigration' in the sediment following endogenous tidal/dial rhythms and environmental stimuli (Saburova and Polikarpov, 2003;
Consalvey et al., 2004; Coelho et al., 2011): during daylight emersion, they migrate to the sediment surface, while during immersion they migrate to deeper sediment layers.

To prevent photoinhibition (Serôdio et al., 2008), benthic diatoms utilize behavioural and physiological responses (Mouget et al., 2008; van Leeuwe et al., 2009; Perkins et al., 2010b; Cartaxana et al., 2011; Serôdio et al., 2012). Behavioural photoprotection involves motility, allowing cells to position themselves in light gradients and escape from prolonged exposure to excess light (Admiraal, 1984; Kromkamp et al., 1998; Consalvey et al., 2004; Serôdio et al., 2006). In addition, both motile and non-motile species use fast regulatory physiological processes for photoprotection (that is, 'physiological photoprotection'; Lavaud, 2007; Goss and Jakob, 2010; Depauw et al., 2012; Lepetit et al., 2012). In diatoms, two processes are important in field situations (Lavaud, 2007): photosystem II cyclic electron transfer (PSII CET) and NPQ of chlorophyll (Chl) fluorescence (Depauw et al., 2012; Lepetit et al., 2012; Lavaud and Lepetit, 2013). NPQ is controlled by several regulatory partners including the lightdependent conversion of diadinoxanthin (DD) to diatoxanthin (DT) by the DD de-epoxidase (that is, the XC) (Brunet and Lavaud, 2010; Goss and Jakob, 2010). In benthic diatoms, however, XC-NPQ has only rarely been studied, and mostly in situ: it has been shown to vary with diurnal and tidal cycles, season, latitude (Serôdio et al., 2005; van Leeuwe et al., 2009; Chevalier et al., 2010), the organisms' position within the sediments and along the intertidal elevation gradient (Jesus et al., 2009; Cartaxana et al., 2011). On the basis of their in situ measurements, the latter authors hypothesized the existence of a trade-off between behavioural and physiological photoprotection mechanisms in benthic diatoms, as a stronger XC was shown to occur in sandy vs muddy sediments. However, at least the sandy sediments contained a mix of both epipsammic and epipelic forms (Jesus et al., 2009; Cartaxana et al., 2011), and even when the latter are not numerically dominant, they can still make a substantial contribution to biomass because of their much larger biovolumes (see for example, Hamels et al. 1998).

Our study represents a comprehensive characterization of fast regulatory physiological photoprotection capacity in typical representatives of the major diatom growth forms occurring in intertidal marine sediments. Given the highly dynamic and often extreme intertidal light climate, we hypothesize that photoprotective features are key traits shaping niche differentiation between benthic growth forms, as has been proposed before for phytoplankton (Huisman et al., 2001; Litchman and Klausmeier, 2008; Dimier et al., 2009; Petrou et al., 2011; Lavaud and Lepetit, 2013). In this respect, we predict that the largely immotile epipsammic life forms are better able to cope with pronounced and rapid changes in light intensity at the physiological level than the motile 
epipelic forms, which can actively position themselves in the sediment light gradient.

\section{Materials and methods}

Diatom culturing and harvesting

Fifteen benthic diatom strains were used (Table 1). All species were assigned to their respective growth form on the basis of microscopical observations on natural assemblages. They were grown in batch cultures at $20^{\circ} \mathrm{C}$ in sterile artificial $\mathrm{F} / 2$ seawater medium enriched with $\mathrm{NaHCO}_{3}\left(80 \mathrm{mgl}^{-1}\right.$ final concentration). TYCHO species were also grown in continuously flushed airlift (that is, with air bubbling) to mimic 'planktonic' growth conditions. Two light intensities (E, 20 and $75 \mu \mathrm{mol}$ photons $\mathrm{m}^{-2} \mathrm{~s}^{-1}$ ) were used with a 16-h light:8-h dark photoperiod white fluorescent tubes, L58W/840, OSRAM, Munich, Germany. Cultures were photoacclimated to the above conditions at least 2 weeks before measurements and experiments (see below). Diatom suspensions for the experiments were prepared to a final concentration of $10 \mu \mathrm{g}$ Chl $a \mathrm{ml}^{-1}$. For this purpose, Chl a concentration was determined according to the Jeffrey and Humphrey (1975) spectrophotometric method. Diatom suspensions were continuously stirred at $20^{\circ} \mathrm{C}$ under the growth $\mathrm{E}$ (that is, 20 or $75 \mu \mathrm{mol}$ photons $\mathrm{m}^{-2} \mathrm{~s}^{-1}$ ) at least $1 \mathrm{~h}$ before the start of the experiments and all along the course of the experiments (Lavaud et al., 2007). This kept the photosynthetic machinery in an oxidized state and prevented NPQ.

\section{Growth rates and biovolumes}

Specific growth rates, $\mu\left(\right.$ day $\left.^{-1}\right)$, were calculated from regression of the natural logarithm of the number of diatom cells during their exponential growth phase as microscopically determined in a Malassez's counting chamber. Biovolumes $\left(\mu \mathrm{m}^{3}\right)$ were calculated using the formula of Hillebrand et al. (1999) based on measurements performed on 15 specimens per species.

\section{High-performance liquid chromatography pigment} analyses

Chl $a$, Chl $c$, fucoxanthin, DD, DT and $\beta$-carotene content, all normalized to Chl $a$ (that is, expressed as mol. $100 \mathrm{~mol} \mathrm{Chl} a^{-1}$ ), were measured using

Table 1 List of the 15 diatom species used in this study with their growth form classification, collection number, origin and average biovolume

\begin{tabular}{|c|c|c|c|c|}
\hline Species & Growth form & Collection $n^{\circ}$ & Sampling place & $\begin{array}{c}\text { Average } \\
\text { biovolume }\left(\mu \mathrm{m}^{3}\right)\end{array}$ \\
\hline $\begin{array}{l}\text { Craspedostauros britannicus } \\
\text { C.b. }\end{array}$ & EPL & NCC195-06-2 & $\begin{array}{l}\text { Pouliguen, Atlantic, } \\
\text { France }\end{array}$ & 1740 \\
\hline $\begin{array}{l}\text { Entomoneis paludosa } \\
\text { E.p. }\end{array}$ & & NCC18-1 & $\begin{array}{l}\text { Bay of Bourgneuf, Atlantic, } \\
\text { France }\end{array}$ & 1081 \\
\hline $\begin{array}{l}\text { Halamphora coffeaeformis } \\
\text { H.c. }\end{array}$ & & UTCC58 & $\begin{array}{l}\text { Victoria, British Columbia, Pacific, } \\
\text { Canada }\end{array}$ & 126 \\
\hline $\begin{array}{l}\text { Navicula phyllepta } \\
\text { N.p. }\end{array}$ & & CCY9804 & $\begin{array}{l}\text { Westerschelde estuary, North sea, } \\
\text { The Netherlands }\end{array}$ & 218 \\
\hline $\begin{array}{l}\text { Seminavis robusta } \\
\text { S.r. }\end{array}$ & & DCG 0105 & $\begin{array}{l}\text { Progeny of strains from Veerse Meer, } \\
\text { The Netherlands }\end{array}$ & 1790 \\
\hline $\begin{array}{l}\text { Amphora sp. } \\
\text { A. sp. }\end{array}$ & Motile (EPM-M) & DCG 0493 & $\begin{array}{l}\text { Rammekenshoek, North sea, } \\
\text { The Netherlands }\end{array}$ & 39 \\
\hline $\begin{array}{l}\text { Nitzschia } \text { cf. frustulum } \\
\text { N.f. }\end{array}$ & & DCG 0494 & $\begin{array}{l}\text { Rammekenshoek, North Sea, } \\
\text { The Netherlands }\end{array}$ & 29 \\
\hline $\begin{array}{l}\text { Planothidium delicatulum } \\
\text { P.d. }\end{array}$ & & NCC363 & $\begin{array}{l}\text { Bay of Bourgneuf, Atlantic, } \\
\text { France }\end{array}$ & 242 \\
\hline $\begin{array}{l}\text { Biremis lucens } \\
\text { B.l. }\end{array}$ & Non-motile (EPM-NM) & NCC360.2 & $\begin{array}{l}\text { Bay of Bourgneuf, Atlantic, } \\
\text { France }\end{array}$ & 242 \\
\hline $\begin{array}{l}\text { Fragilaria cf. subsalina } \\
\text { F.s. }\end{array}$ & & DCG 0492 & $\begin{array}{l}\text { Rammekenshoek, North sea, } \\
\text { The Netherlands }\end{array}$ & 165 \\
\hline $\begin{array}{l}\text { Opephora sp. } \\
\text { O. sp. }\end{array}$ & & DCG 0448 & $\begin{array}{l}\text { Rammekenshoek, North Sea, } \\
\text { The Netherlands }\end{array}$ & 86 \\
\hline $\begin{array}{l}\text { Plagiogramma staurophorum } \\
\text { P. s. }\end{array}$ & & DCG 0495 & $\begin{array}{l}\text { Rammekenshoek, North sea, } \\
\text { The Netherlands }\end{array}$ & ND \\
\hline $\begin{array}{l}\text { Brockmanniella brockmannii } \\
\text { B.b. }\end{array}$ & TYCHO & NCC161 & $\begin{array}{l}\text { Bay of Bourgneuf, Atlantic, } \\
\text { France }\end{array}$ & 105 \\
\hline $\begin{array}{l}\text { Cylindrotheca closterium } \\
\text { C.c. }\end{array}$ & & $\begin{array}{l}\text { Collection } \\
\text { Univ. Aveiro }\end{array}$ & $\begin{array}{l}\text { Ria de Aveiro, Atlantic, } \\
\text { Portugal }\end{array}$ & 247 \\
\hline $\begin{array}{l}\text { Plagiogrammopsis vanheurckii } \\
\text { P.v. }\end{array}$ & & NCC186-2 & $\begin{array}{l}\text { Bay of Bourgneuf, Atlantic, } \\
\text { France }\end{array}$ & 737 \\
\hline
\end{tabular}

Abbreviations: CCY, Culture Collection Yerseke-The Netherlands; DCG: BCCM (Belgian Coordinated Collections of Microorganisms) Diatom Culture Collection hosted by Laboratory for Protistology \& Aquatic Ecology, Ghent University, Belgium; EPL, epipelon; EPM, epipsammon; NCC, Nantes Culture Collection-France; ND, not determined; TYCHO, tychoplankton; UTCC, University of Toronto Culture Collection of Algae and Cyanobacteria-Canada (now the Canadian Phycological Culture Collection, CPCC). 
high-performance liquid chromatography as described in Jakob et al. (1999). One millilitre of diatom suspension was rapidly filtered (Isopore $1.2 \mu \mathrm{m}$ RTTP filters, Merck Millipore, Darmstadt, Germany) and immediately frozen in liquid nitrogen before extraction in a cold $\left(4{ }^{\circ} \mathrm{C}\right)$ mixture of $90 \%$ methanol $/ 0.2 \mathrm{M}$ ammonium acetate (90/10 vol $/ \mathrm{vol}$ ) and $10 \%$ ethyl acetate. The pigment extraction was improved by the use of glass beads (diameter 0.25-0.5 mm, Roth, Karlsruhe, Germany) and included several short (20 s) vortexing steps. Supernatants were collected after centrifugation ( $5 \mathrm{~min}$, $10000 \mathrm{~g}, 4^{\circ} \mathrm{C}$ ) and immediately injected into an high-performance liquid chromatography system (Hitachi Lachrom Elite, Tokyo, Japan) equipped with a cooled auto-sampler and a photodiode array detector (L-2455). Chromatographic separation was carried out using a Nucleosil 120-5 C18 column (125 mm long, $4 \mathrm{~mm}$ internal diameter, $5 \mu \mathrm{m}$ particles, Macherey-Nagel, Düren, Germany) equipped with a pre-column (CC 8/4 Nucleosil, MachereyNagel) for reverse phase chromatography during a 25-min elution program. The solvent gradient followed Jakob et al. (1999) with an injection volume of $50 \mu \mathrm{l}$ and a flow rate of $1.5 \mathrm{ml} \mathrm{min}^{-1}$. Pigments were identified from absorbance spectra $(400-800 \mathrm{~nm})$ and retention times (Roy et al., 2011), and their concentrations were obtained from the signals in the photodiode array detector at $440 \mathrm{~nm}$. The de-epoxidation state (DES in \%) was calculated as $((\mathrm{DT} / \mathrm{DD}+\mathrm{DT}) \times 100)$, where $\mathrm{DD}$ is the epoxidized form and DT is the de-epoxidized form. Chl $a$ concentration per cell was determined during exponential growth based on cell counts (see above) and the Chl $a$ measurements.

\section{Chl fluorescence yield and light curves}

For a complete overview of the definition and measurement of the photophysiological parameters, see Table 2. Chl fluorescence yield was monitored with a Diving-PAM fluorometer (Walz, Effeltrich, Germany) on a $2.5 \mathrm{ml}$ stirred and $20^{\circ} \mathrm{C}$ controlled diatom suspension (Lavaud et al., 2004). Before measurement, the cells were dark-adapted for $15 \mathrm{~min}$, and a saturating pulse $(3600 \mu \mathrm{mol}$ photons $\mathrm{m}^{-2} \mathrm{~s}^{-1}$, duration $0.4 \mathrm{~ms}$ ) was fired to measure $F_{0}, F_{m}$ and $F_{v} / F_{m}$. Two types of light curves were performed: non-sequential and rapid light curves (Perkins et al., 2010a). For non-sequential light curves, continuous light (KL-2500 lamp, Schott, Mainz, Germany) was applied for $5 \mathrm{~min}$ at different Es (48-1950 $\mu \mathrm{mol}$ photons $\mathrm{m}^{-2} \mathrm{~s}^{-1}$ ); a new diatom suspension was used for each $\mathrm{E}$. At the end of each exposure, $\mathrm{F}_{\mathrm{m}}$ ' and NPQ were measured. For rapid light curves, one diatom suspension was exposed to eight successive, incrementally increasing Es (29-1042 $\mu \mathrm{mol}$ photons $\mathrm{m}^{-2} \mathrm{~s}^{-1}$ ) of $30-\mathrm{s}$ each (Perkins et al., 2006; Supplementary Table S1). Rapid light curves allow constructing relative electron transport rate (rETR) vs E and NPQ vs E curves. The NPQ vs E curve is based on a 3-parameter Hill equation model and it is described by the equation $\mathrm{NPQ} \quad(\mathrm{E})=\mathrm{NPQ}_{\mathrm{m}} \times\left[\mathrm{E}^{\mathrm{nNPQ}} /\left(\mathrm{E} 50_{\mathrm{NPQ}}{ }^{\mathrm{nNQ}}+\right.\right.$ $E^{\text {nNPQ'})] ~(S e r o ̂ d i o ~ a n d ~ L a v a u d, ~ 2011) . ~ F r o m ~ t h e ~ f i t t e d ~}$ rETR-E curves (Eilers and Peeters, 1988) and NPQ-E curves (Serôdio and Lavaud, 2011), $\mathrm{rETR}_{\mathrm{m}}, \alpha, \mathrm{E}_{\mathrm{k}}$, and $\mathrm{NPQ}_{\mathrm{m}}, \mathrm{E} 50_{\mathrm{NPQ}}, \mathrm{n}_{\mathrm{NPQ}}$ can be derived, respectively. All parameters are described in the Table 2. $\mathrm{n}_{\mathrm{NPQ}}$ is the Hill coefficient or the sigmoidicity coefficient of the NPQ-E curve (Serôdio and Lavaud, 2011). It informs on the onset of NPQ at moderate Es, that is, when the DT molecules are being 'activated' with increasing Es to effectively participate to NPQ: DT 'activation' depends on its enzymatic conversion and its binding to the PSII light-harvesting antenna complex in order to promote the antenna switch to a dissipative state of excess energy, which is measurable by NPQ (see Lavaud and Lepetit, 2013). When $\mathrm{n}_{\mathrm{NPQ}}$ is $<1$, the NPQ-E curve shows an asymptotic saturation-like increase toward $\mathrm{NPQ}_{\mathrm{m}}$, while when $\mathrm{n}_{\mathrm{NPQ}}$ is $>1$, the NPQ-E curve shows a sigmoidal shape. In the later case, the Hill reaction (that is, NPQ onset) is allosteric (as proposed for the NPQ mechanism, see Lavaud and Lepetit, 2013), $\mathrm{n}_{\mathrm{NPQ}}$ thus informing on the degree of allostery of the NPQ-E curve. The higher $\mathrm{n}_{\mathrm{NPQ}}$, the more positively cooperative the Hill reaction is; $\mathrm{n}_{\mathrm{NPQ}}$ around 2 being the highest values reported so far (Serôdio and Lavaud, 2011). The same fitting procedure can obviously be used for the DT-E and the DESE curves, thereby extracting analogous parameters as from the fitted NPQ-E curves.

\section{$\mathrm{O}_{2}$ yield and the PSII CET}

The relative $\mathrm{O}_{2}$ yield produced during a sequence of single-turnover saturating flashes at a frequency of $2 \mathrm{~Hz}$ was measured with a home-made rate electrode (Lavaud et al., 2002). The steady-state $\mathrm{O}_{2}$ yield per flash $\left(\mathrm{Y}_{\mathrm{SS}}\right)$ was attained for the last four flashes of a sequence of 20 when the S-state cycle oscillations were fully damped (Lavaud et al., 2002). $\mathrm{Y}_{\mathrm{SS}}$ of 15-min dark-adapted ( ${ }_{\mathrm{D}}$ ) and illuminated ( $\mathrm{L}_{\mathrm{L}}$, samples taken at the end of each non-sequential light curve) cells was used to calculate the PSII CET (Lavaud et al., 2002, 2007) as follows: $\left[\left\{\left(20 \times \mathrm{Y}_{\mathrm{SS}} \mathrm{L}\right)-(\Sigma\right.\right.$ $\left.\left.\left.\left(\mathrm{Y}_{1 \ldots 20}\right)_{\mathbf{L}}\right)\right\}-\left\{\left(20 \times \mathrm{Y}_{\text {SS } \mathbf{D}}\right)-\left(\Sigma\left(\mathrm{Y}_{1 \ldots 20}\right)_{\mathbf{D}}\right)\right\}\right] / \mathrm{Y}_{\text {SS } \mathbf{D}}$.

\section{Statistics}

Statistical analyses were conducted using the statistical software package SAS 9.3 (Cary, NC, USA). Species were compared using the general linear model PROC GLM. Growth forms (groups) were compared using the mixed linear model PROC MIXED. Groups were regarded as fixed effects. Data were log transformed or square root transformed when needed to allow the best possible fit. Where necessary, estimated least squares means (lsmeans) and standard errors (s.e.) were back transformed as in Jørgensen and Pedersen (1998). 
Table 2 Photophysiological parameters used in this study, their photophysiological meaning and measurement method and conditions

\begin{tabular}{|c|c|c|c|c|}
\hline Parameter & Unit & Definition & Photophysiological meaning & Measurement conditions \\
\hline $\mathrm{F}_{\mathrm{o}}$ & No units & $\begin{array}{l}\text { Minimum PSII Chl fluorescence } \\
\text { yield }\end{array}$ & $\begin{array}{l}\text { Used to calculate } \mathrm{F}_{\mathrm{v}} / \mathrm{F}_{\mathrm{m}} \text { (see } \\
\text { below) }\end{array}$ & $\begin{array}{l}\text { Measured with NSLCs after } 15 \text { min of dark } \\
\text { acclimation }\end{array}$ \\
\hline $\mathrm{F}_{\mathrm{m}}$ & No units & $\begin{array}{l}\text { Maximum PSII Chl fluorescence } \\
\text { yield }\end{array}$ & $\begin{array}{l}\text { Used to calculate } F_{v} / F_{m} \text { and } \\
\text { NPQ (see below) }\end{array}$ & $\begin{array}{l}\text { Measured with NSLCs during a saturating } \\
\text { pulse after } 15 \text { min of dark acclimation }\end{array}$ \\
\hline $\mathrm{F}_{\mathrm{v}} / \mathrm{F}_{\mathrm{m}}$ & No units & $\begin{array}{l}\text { Maximum photosynthetic } \\
\text { efficiency of PSII; } \mathrm{F}_{\mathrm{v}}=\mathrm{F}_{\mathrm{m}}-\mathrm{F}_{0}\end{array}$ & $\begin{array}{l}\text { Maximum quantum effi- } \\
\text { ciency of PSII } \\
\text { photochemistry }\end{array}$ & $\begin{array}{l}\text { See the above measurement conditions for } \\
\mathrm{F}_{0} \text { and } \mathrm{F}_{\mathrm{m}}\end{array}$ \\
\hline $\mathrm{F}_{\mathrm{m}}{ }^{\prime}$ & No units & $\mathrm{F}_{\mathrm{m}}$ for illuminated cells & $\begin{array}{l}\text { Used to measure NPQ and } \\
\text { rETR }\end{array}$ & $\begin{array}{l}\text { Measured with NSLCs during a saturating } \\
\text { pulse after } 5 \text { min of illumination at specific } \\
\text { E }\end{array}$ \\
\hline NPQ & No units & $\begin{array}{l}\text { Non-photochemical quenching } \\
\text { of Chl fluorescence; NPQ = } \\
\mathrm{F}_{\mathrm{m}} / \mathrm{F}_{\mathrm{m}}{ }^{\prime}-1\end{array}$ & $\begin{array}{l}\text { Estimates the photoprotec- } \\
\text { tive dissipation of excess } \\
\text { energy }\end{array}$ & Measured with NSLCs \\
\hline rETR & $\begin{array}{l}\mu \mathrm{mol} \text { electrons } \\
\mathrm{m}^{-2} \mathrm{~s}^{-1}\end{array}$ & $\begin{array}{l}\text { Relative electron transport rate } \\
\text { of PSII; } r E T R=\Phi P S I I \times E \text { where } \\
\Phi P S I I=F_{m}{ }^{\prime}-F / F_{m},\end{array}$ & $\begin{array}{l}\text { Effective quantum yield of } \\
\text { photochemistry vs E }\end{array}$ & $\begin{array}{l}\text { Measured with RLCs; F is the steady-state } \\
\text { of Chl fluorescence measured after } 30-\mathrm{s} \\
\text { illumination at a given E }\end{array}$ \\
\hline$\alpha$ & Relative units & rETR-E curve initial slope & $\begin{array}{l}\text { Maximum light efficiency } \\
\text { use }\end{array}$ & $\begin{array}{l}\text { Derived from fitted rETR-E curves mea- } \\
\text { sured with RLCs (Eilers and Peeters, 1988) }\end{array}$ \\
\hline $\mathrm{rETR}_{\mathrm{m}}$ & $\begin{array}{l}\mu \mathrm{mol} \text { electrons } \\
\mathrm{m}^{-2} \mathrm{~s}^{-1}\end{array}$ & rETR-E curve asymptote & $\begin{array}{l}\text { Maximum relative photo- } \\
\text { synthetic electron transport } \\
\text { rate }\end{array}$ & $\begin{array}{l}\text { Derived from fitted rETR-E curves mea- } \\
\text { sured with RLCs (Eilers and Peeters, 1988) }\end{array}$ \\
\hline $\mathrm{E}_{\mathrm{k}}$ & $\begin{array}{l}\mu \mathrm{mol} \text { photons. } \\
\mathrm{m}^{-2} \cdot \mathrm{s}^{-1}\end{array}$ & $\mathrm{E}_{\mathrm{k}}=\mathrm{rETR}_{\mathrm{m}} / \alpha$ & Light saturation coefficient & $\begin{array}{l}\text { Derived from fitted rETR-E curves mea- } \\
\text { sured with RLCs (Eilers and Peeters, 1988) }\end{array}$ \\
\hline $\mathrm{NPQ}_{\mathrm{m}}$ & No units & NPQ-E curve asymptote & Maximum NPQ & Measured with NSLCs \\
\hline $\mathrm{E} 50_{\mathrm{NPQ}}$ & $\begin{array}{l}\mu \mathrm{mol} \text { photons. } \\
\mathrm{m}^{-2} \cdot \mathrm{s}^{-1}\end{array}$ & $\mathrm{E}$ for reaching $50 \%$ of $\mathrm{NPQ}_{\mathrm{m}}$ & $\begin{array}{l}\text { Pattern of NPQ induction vs } \\
\text { E }\end{array}$ & $\begin{array}{l}\text { Derived from fitted NPQ-E curves (Serôdio } \\
\text { and Lavaud, 2011) measured with NSLCs }\end{array}$ \\
\hline $\mathrm{n}_{\mathrm{NPQ}}$ & No units & $\begin{array}{l}\text { NPQ-E curve sigmoidicity } \\
\text { coefficient }\end{array}$ & $\begin{array}{l}\text { Onset of NPQ induction for } \\
\text { moderate Es }\left(<\mathrm{E} 50_{\mathrm{NPQ}}\right)\end{array}$ & $\begin{array}{l}\text { Derived from fitted NPQ-E curves (Serôdio } \\
\text { and Lavaud, 2011) measured with NSLCs }\end{array}$ \\
\hline $\mathrm{DT}_{\mathrm{m}}$ & $\begin{array}{l}\text { mol. } 100 \mathrm{~mol} \\
\text { Chl } a^{-1}\end{array}$ & DT-E curve asymptote & Maximum DT concentration & Measured with NSLCs \\
\hline E50 & $\begin{array}{l}\mu \mathrm{mol} \text { photons. } \\
\mathrm{m}^{-2} \cdot \mathrm{s}^{-1}\end{array}$ & $\mathrm{E}$ for reaching $50 \%$ of $\mathrm{DT}_{\max }$ & Pattern of DT synthesis vs E & $\begin{array}{l}\text { Derived from fitted DT-E curves (Serôdio } \\
\text { and Lavaud, 2011) measured with NSLCs }\end{array}$ \\
\hline $\mathrm{n}_{\mathrm{DT}}$ & No units & $\begin{array}{l}\text { DT-E curve sigmoidicity } \\
\text { coefficient }\end{array}$ & $\begin{array}{l}\text { Onset of DT synthesis for } \\
\text { moderate Es }\left(<\mathrm{E} 50_{\mathrm{NPQ}}\right)\end{array}$ & $\begin{array}{l}\text { Derived from fitted DT-E curves (Serôdio } \\
\text { and Lavaud, 2011) measured with NSLCs }\end{array}$ \\
\hline $\mathrm{DES}_{\mathrm{m}}$ & $\%$ & $\begin{array}{l}\text { DES-E curve asymptote; DES }= \\
(\mathrm{DT} /(\mathrm{DD}+\mathrm{DT}) \times 100)\end{array}$ & $\begin{array}{l}\text { Maximum de-epoxidation } \\
\text { state }\end{array}$ & Measured with NSLCs \\
\hline NPQ / DT & No units & NPQ-DT curve slope & $\begin{array}{l}\text { Effective involvement of DT } \\
\text { in NPQ for all Es (Lavaud } \\
\text { and Lepetit, 2013) }\end{array}$ & Measured with NSLCs \\
\hline
\end{tabular}

Abbreviations: Chl, chlorophyll; DD, diadinoxanthin; DT, diatoxanthin; E, light intensity; NPQ, non-photochemical quenching; NSLCs, non-sequential light curves; PSII, photosystem II; RLCs, rapid light curves. See the Materials and methods section for further details.

\section{Results}

Growth rate and photosynthetic properties

The Chl a concentration per cell showed an exponential relationship with biovolume with relatively small changes at the smaller cell volumes (Supplementary Figure S1). The average diatom biovolumes were independent of growth form (Table 3, Supplementary Figure S1). Growth rate did not differ significantly between the growth forms at growth $\mathrm{E}=20 \mu \mathrm{mol}$ photons $\mathrm{m}^{-2} \mathrm{~s}^{-1}$ (Table 3, Supplementary Table S2). Relative concentrations of the light-harvesting pigments Chl $C$ and fucoxanthin were comparable among growth forms (Table 3, Supplementary Table S2). $\beta$-Carotene, which is mainly associated with the photosystem cores, was only slightly but significantly higher in EPL than in EPM-NM. DD + DT content was significantly lower in EPL than in the other growth forms. As the cells were grown at low E, DES was generally low, with no significant differences between the growth forms (Table 3, Supplementary Table S2). The highest DD + DT $(16.95 \pm 2.56 \mathrm{~mol}$ $\left.100 \mathrm{~mol} \mathrm{Chl} a^{-1}\right)$ and DES (16.4 $\left.\pm 6.2 \%\right)$ values were observed in Plagiogramma staurophorum (EPMNM) (Supplementary Table S3). There were no significant differences in $\mathrm{F}_{\mathrm{v}} / \mathrm{F}_{\mathrm{m}}, \alpha, \mathrm{rETR}_{\mathrm{m}}, \mathrm{E}_{\mathrm{k}}$ and PSII CET $\mathrm{Cax}_{\max }$ between the growth forms. $\mathrm{E}_{\mathrm{k}}$ was on average three to four times the growth $\mathrm{E}$ in all growth forms (Table 3, Supplementary Table S2). PSII $\mathrm{CET}_{\mathrm{m}}$ was close to 3 (its maximum, Lavaud et al., 2002) for the two EPM growth forms, and about 2 in EPL and TYCHO (Table 3).

\section{$N P Q$ properties}

At $\mathrm{E}$ values $\geqslant 230 \mu \mathrm{mol}$ photons $\mathrm{m}^{-2} \mathrm{~s}^{-1}$, NPQ was significantly higher in EPM-NM than in both EPL and TYCHO; the same holds true for EPM-M vs EPL and TYCHO at $\mathrm{E}$ values $\geqslant 1050 \mu \mathrm{mol}$ photons $\mathrm{m}^{-2}$ $\mathrm{s}^{-1}$ (Figure 1, Supplementary Table S4). NPQ was also significantly higher in EPM-NM than in EPM-M 
except at the lowest and highest E values. Similarly, $\mathrm{NPQ}_{\mathrm{m}}$ was significantly higher $(\times 3.5$ and $\times 2.4$, respectively) in EPM-NM and EPM-M than in EPL and TYCHO (Figure 1, Table 4 and Supplementary Tables S5 and S6). In EPL and TYCHO, the NPQ-E curves showed a lower variability than in the two EPM growth forms (Supplementary Figure S2). EPM$\mathrm{NM}$ had the lowest $\mathrm{E} 50_{\mathrm{NPO}}$, significantly lower than all other groups (Table 4, Supplementary Tables S5 and S6). In contrast, TYCHO E50 $0_{\mathrm{NPQ}}$ was significantly higher than in the other groups. EPL and EPM-M E50 $0_{\mathrm{NPO}}$ did not differ significantly from each other. In contrast, $\mathrm{n}_{\mathrm{NPQ}}$ was not significantly different and varied around its optimum (that is, 2, Serôdio and Lavaud, 2011) in most species except the TYCHO ones (which is significantly lower than in EPM-NM) (Table 4, Supplementary Tables S5 and S6).

\section{XC properties}

DES was only significantly different between EPL and both TYCHO and EPM-M at $105 \mu \mathrm{mol}$ photons $\mathrm{m}^{-2} \mathrm{~s}^{-1}$ and between EPL and both EPM forms at $230 \mu \mathrm{mol}$ photons $\mathrm{m}^{-2} \mathrm{~s}^{-1}$ (Figure 1, Supplementary Table S7). $\mathrm{DES}_{\mathrm{m}}$ varied between $21.2 \pm 3.4$ for EPL, $22.7 \pm 4.4$ for TYCHO, $28.7 \pm 4.4$ for EPM-M and $29.4 \pm 3.8$ for EPM-NM (lsmeans \pm s.e.) (Figure 1, Table 4 and Supplementary Tables S5 and S6). The slight difference between EPL and the EPM growth forms, although not significant, in combination with the significantly higher DD + DT in the latter, generated a significantly lower $\mathrm{DT}_{\mathrm{m}}$ in EPL than in the EPM growth forms (Tables 3 and 4, Supplementary Tables S2 and S6). E50 Dт was close to the $\mathrm{E} 50_{\mathrm{NPQ}}$ in all growth forms except in TYCHO where it was lower; no significant differences between the EPM and EPL were observed, only EPM-NM and TYCHO E50 (Table 4, Supplementary Tables S5 and S6). $\mathrm{n}_{\mathrm{DT}}$ was significantly lower in EPM-M and TYCHO than in EPL and EPM-NM. NPQ/DT was about half its optimum ( $=1$ under these experimental conditions) in all groups except EPM-NM (Table 4, Supplementary Tables S5 and S6). It roughly followed the same order as observed for $\mathrm{NPQ}_{\mathrm{m}}$, that is, $\mathrm{EPM}-\mathrm{NM}>\mathrm{EPM}-\mathrm{M}>\mathrm{EPL} \cong \mathrm{TYCHO}$, with a $2 \times$ higher value in EPM-NM (Table 4). The difference between EPM-NM and the other growth forms, however, was not significant because of the low NPQ/DT value in Plagiogramma staurophorum (Supplementary Table S5). Figure 2 shows that in all growth forms except EPM-M there were species (Seminavis robusta, Fragilaria. cf. subsalina, P. staurophorum, Brockmanniella brockmannii) for which a low NPQ developed without DT synthesis, while two EPM-M species (Amphora sp. and Planothidium delicatulum) showed DT synthesis $\left(0.17 \pm 0.03 \mathrm{~mol} 100 \mathrm{~mol}\right.$ Chl $\left.a^{-1}\right)$ without NPQ (see also Supplementary Table S5). All other species showed a NPQ/DT relationship with an origin close to 0 , as expected. 
a

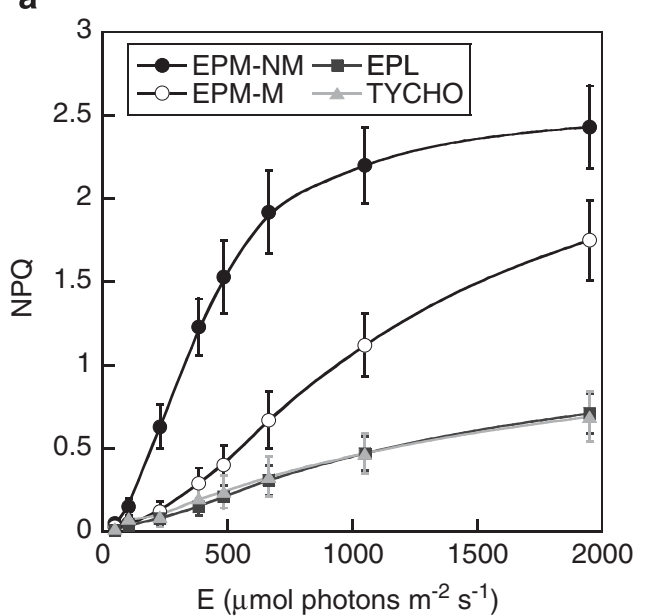

b

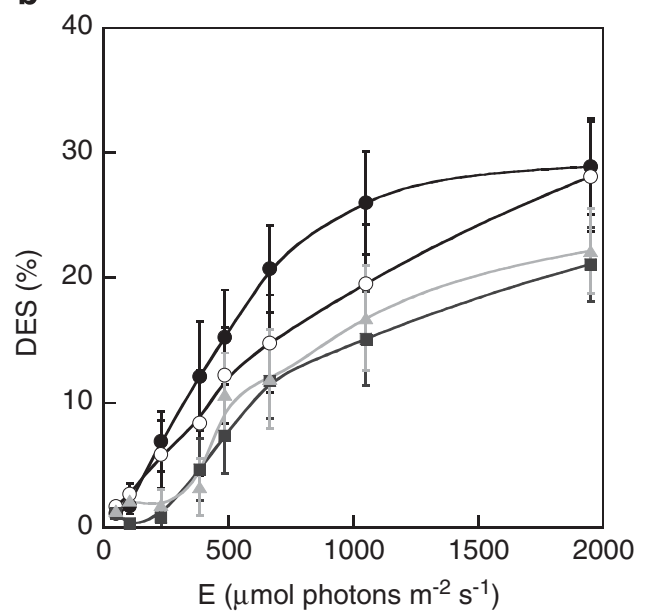

C

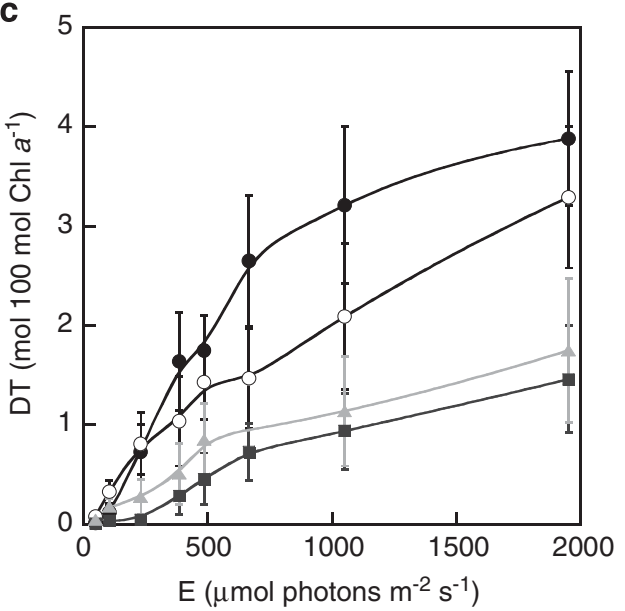

Figure 1 NPQ of Chl fluorescence (a), DES of the DD to DT $(\mathrm{DES}=\mathrm{DT} /(\mathrm{DD}+\mathrm{DT}) \times 100)(\mathbf{b})$ and $\mathrm{DT}$ content $(\mathbf{c})$ as a function of light intensity ( $\mathrm{E}$ from darkness to $1950 \mu \mathrm{mol}$ photons $\mathrm{m}^{-2} \mathrm{~s}^{-1}$, which is equivalent to full sunlight in the field) measured during non-sequential light curves (NSLCs) in the four benthic diatom growth forms (EPL, epipelon; EPM-M, epipsammon motile; EPM-NM, epipsammon non-motile; TYCHO, tychoplankton). Cells were grown at $20 \mu \mathrm{mol}$ photons $\mathrm{m}^{-2} \mathrm{~s}^{-1}$. The NPQ-E curves for the individual species can be found in Supplementary Figure S3. Values are estimated least squares means \pm estimated s.e. (PROC MIXED procedure).
Effect of high light acclimation on the NPQ and XC properties

All species were grown under an E $(75 \mu \mathrm{mol}$ photons $\mathrm{m}^{-2} \mathrm{~s}^{-1}$ ) roughly corresponding to the mean $\mathrm{E}_{\mathrm{k}}$ for the low $\mathrm{E}$ acclimated cells $\left(20 \mu \mathrm{mol}\right.$ photons $\mathrm{m}^{-2}$ $\mathrm{s}^{-1}$, Table 3); (Figure 3, Supplementary Table S8). Only EPL had significantly higher growth rates at $75 \mu \mathrm{mol}$ photons $\mathrm{m}^{-2} \mathrm{~s}^{-1}$. DD $+\mathrm{DT}$ significantly increased with a factor 1.6-1.7 in EPL and EPM, and 2.3 in TYCHO. There was a significant increase in DES at $75 \mu \mathrm{mol}$ photons $\mathrm{m}^{-2} \mathrm{~s}^{-1}$ in all growth forms except in EPM-M. The increase in DD + DT and DES at the higher light intensity was most pronounced in TYCHO and resulted in a pronounced, significant difference in both parameters between TYCHO and EPL at this light intensity. The comparison of Chl fluorescence yield and light curve parameters could only be performed for a selection of six species (covering all growth forms) and is summarized in Figure 4 (see also Supplementary Table S9). As expected, the Chl $a$ content per cell decreased, roughly with a factor of 2 in all species (except Navicula phyllepta). There was only a slight (up to about $10 \%$ ) decrease in $\mathrm{F}_{\mathrm{v}} / \mathrm{F}_{\mathrm{m}}$ in all species, illustrating the unstressed state of the cells (note that in Seminavis robusta and Planothidium delicatulum this decrease was slightly significant). $\mathrm{DES}_{\mathrm{m}}$ significantly increased in $S$. robusta only. Together with the overall increase in DD + DT, this resulted in a significant increase in $\mathrm{DT}_{\mathrm{m}}$ (by a factor of 4) in this species, but also in $P$. delicatulum and Plagiogrammopsis vanheurckii. The corresponding $\mathrm{NPQ}_{\mathrm{m}}$ did not follow the same trend: it significantly increased in all species (except for $P$. delicatulum and Opephora sp.) but only by a factor of maximally 2. NPQ/DT remained low (0.2 to 0.5 ) in all species (and significantly decreased in Opephora sp.). E50 ${ }_{\mathrm{NPQ}}$ was significantly higher only in the EPM-NM species Plagiogramma staurophorum.

Effect of 'planktonic' growth on the NPQ and XC properties of tychoplankton

The three TYCHO species were grown under 'planktonic' conditions (at $20 \mu \mathrm{mol}$ photons $\mathrm{m}^{-2} \mathrm{~s}^{-1}$ ) for a comparison with growth under 'benthic' conditions (Figure 5, Supplementary Table S10). Brockmaniella brockmannii responded most strongly to a switch from 'benthic' to 'planktonic' growth: it showed a significantly lower growth rate and a higher DES and $D E S_{m}$ but a lower $\mathrm{NPQ}_{\mathrm{m}}$, suggesting photosynthetic stress and investment of additional DT in other processes than NPQ. Plagiogrammopsis vanheurckii and Cylindrotheca closterium showed very little change, apart from a significantly higher growth rate during planktonic growth in $P$. vanheurckii, a slight decrease in NPQ/DT in $C$. closterium, and an increase in DES in both species. The most pronounced and consistent change in TYCHO thus concerned an increase in DES when grown in suspension. Note that there is also an 
Table 4 NPQ and XC properties of the four growth forms of benthic diatoms

\begin{tabular}{|c|c|c|c|c|c|c|c|c|}
\hline Growth form & $N P Q_{m}$ & $E 50_{N P Q}$ & $n_{N P Q}$ & $D E S_{m}$ & $D T_{m}$ & $E 50_{D T}$ & $n_{D T}$ & $N P Q / D T$ \\
\hline EPL & $0.69 \pm 0.09$ & $866.45 \pm 200.24$ & $1.88 \pm 0.26$ & $21.20 \pm 3.38$ & $1.34 \pm 0.52$ & $714.73 \pm 128.29$ & $2.39 \pm 0.20$ & $0.46 \pm 0.10$ \\
\hline EPM-M & $1.71 \pm 0.28$ & $1061.25 \pm 310.20$ & $2.04 \pm 0.34$ & $28.68 \pm 4.37$ & $3.08 \pm 1.36$ & $809.41 \pm 164.71$ & $1.38 \pm 0.20$ & $0.52 \pm 0.14$ \\
\hline EPM-NM & $2.41 \pm 0.34$ & $360.61 \pm 91.42$ & $2.27 \pm 0.29$ & $29.43 \pm 3.79$ & $3.45 \pm 2.21$ & $465.91 \pm 80.04$ & $2.30 \pm 0.21$ & $0.67 \pm 0.16$ \\
\hline TYCHO & $0.66 \pm 0.11$ & $3887.42 \pm 1105.58$ & $1.12 \pm 0.34$ & $22.73 \pm 4.39$ & $1.78 \pm 0.61$ & $1099.82 \pm 341.05$ & $1.42 \pm 0.19$ & $0.36 \pm 0.10$ \\
\hline
\end{tabular}

Abbreviations: DES, de-epoxidation state; DT, diatoxanthin; EPL, epipelon; EPM-M, motile epipsammon; EPM-NM, non-motile epipsammon; NPQ, non-photochemical quenching; TYCHO, tychoplankton; XC, xanthophyll cycle.

Definitions and conditions of measurement of all parameters are listed in Table 2. The values for the individual species can be found in

Supplementary Table S5. Values are least squares means estimates and estimated s.e. (PROC MIXED procedure).
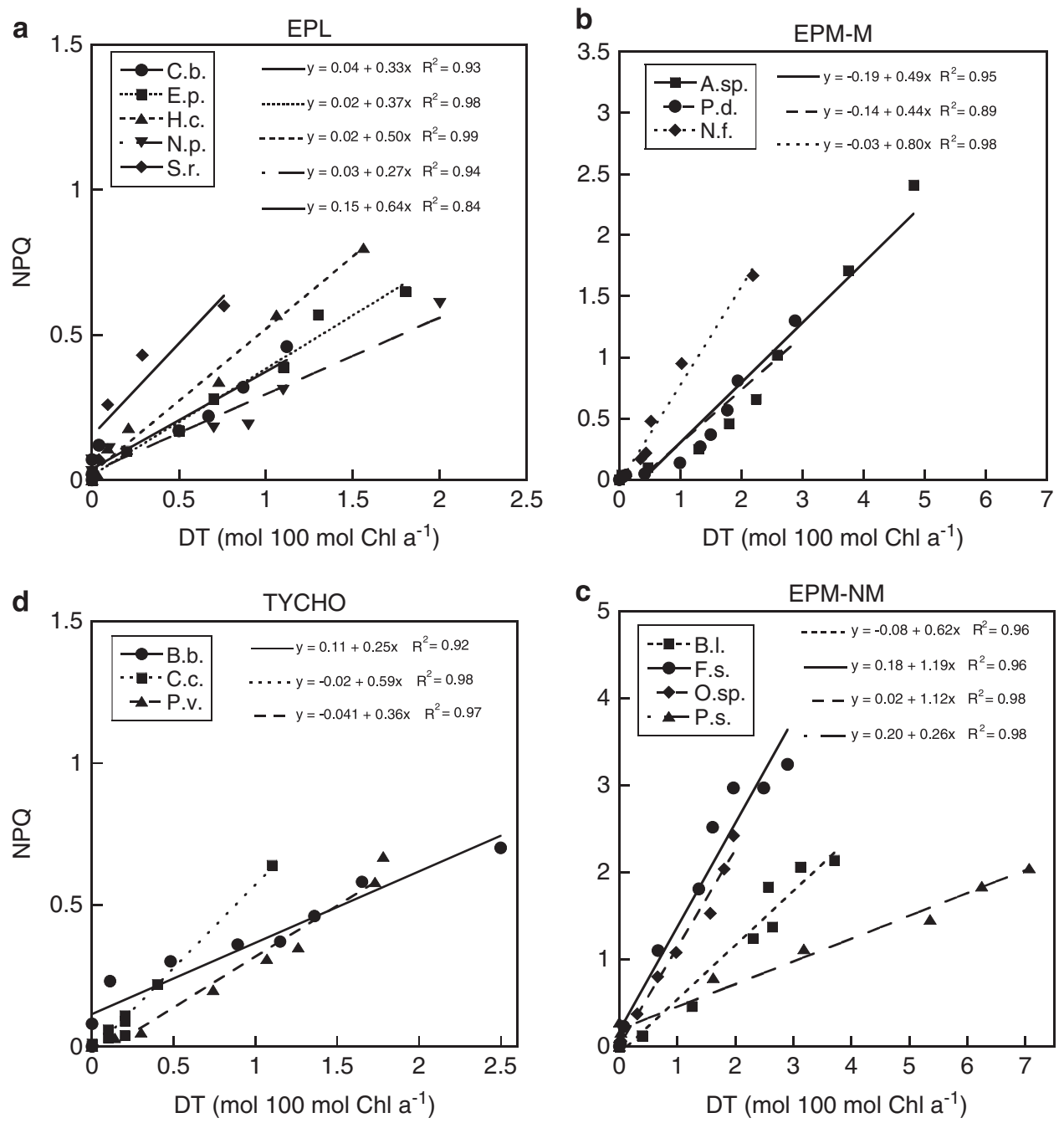

Figure 2 NPQ of Chl fluorescence as a function of the amount of DT measured during non-sequential light curves (NSLCs) in the five species of epipelon (EPL) (a), the four species of motile epipsammon (EPM-NM) (b), the three species of tychoplankton (TYCHO) (c) and the three species of non-motile epipsammon (EPM-NM) (d). Cells were grown at $20 \mu \mathrm{mol}$ photons $\mathrm{m}^{-2} \mathrm{~s}^{-1}$. The full names and classification of all species is listed in Table 1.

overall decrease in $\mathrm{rETR}_{\mathrm{m}}$, but this decrease was just not significant $(P=0.08)$.

\section{Discussion}

The present work constitutes the first comparative experimental study, using unialgal cultures in standardized conditions, of fast regulatory photoprotective mechanisms in the four main benthic diatom growth forms present in intertidal marine sediments (EPL, EPM-M and EPM-NM and TYCHO). As no sediment was added in our experiments, motile diatoms were not able to position themselves in a light gradient, hence effectively incapacitating their behavioural 

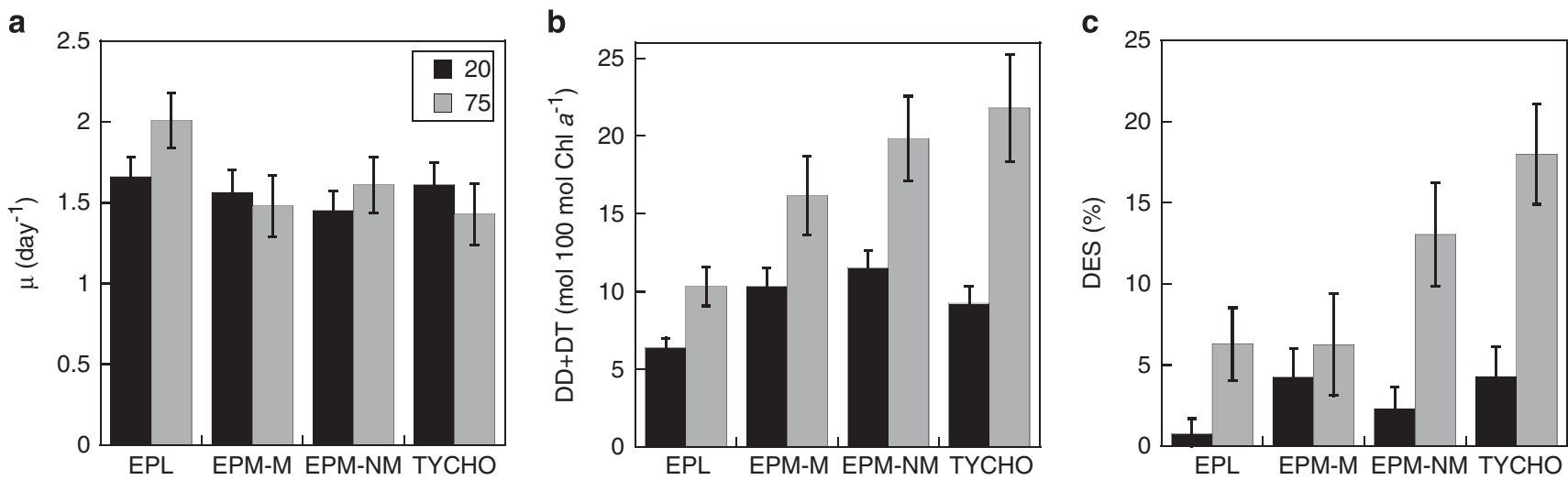

Figure 3 Growth rate $(\mu)(\mathbf{a})$, DD + DT content $(\mathbf{b})$ and DES of DD to DT $(\mathrm{DES}=(\mathrm{DT} / \mathrm{DD}+\mathrm{DT} \times 100)(\mathbf{c})$ in the four benthic diatom growth forms (EPL, epipelon, EPM-M; epipsammon motile; EPM-NM, epipsammon non-motile; TYCHO, tychoplankton) for cells grown at light intensities of 20 and $75 \mu \mathrm{mol}$ photons $\mathrm{m}^{-2} \mathrm{~s}^{-1}$, respectively. All parameters were measured on cells in exponential growth and sampled $2 \mathrm{~h}$ after the onset of light; growth conditions were 16-h light:8-h dark, $20^{\circ} \mathrm{C}$. The values for all species in 20 and $75 \mu \mathrm{mol}$ photons ${ }^{-2}$ $\mathrm{s}^{-1}$ conditions are found in Supplementary Tables S3 and S8, respectively. Values are estimated least squares means \pm estimated s.e. (PROC MIXED procedure).

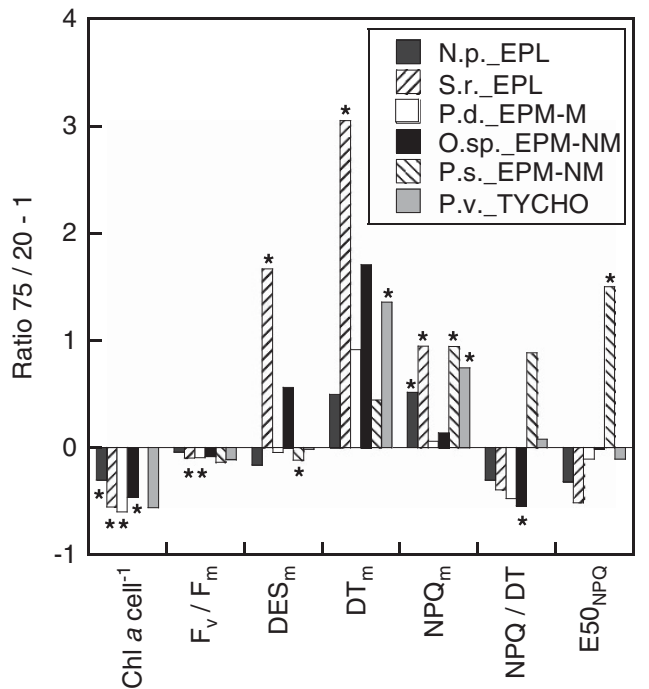

Figure 4 Comparison of photosynthetic, NPQ of Chl fluorescence and XC parameters measured in diatom species representative of the four benthic diatom growth forms grown at light intensities of 20 and $75 \mu \mathrm{mol}$ photons $\mathrm{m}^{-2} \mathrm{~s}^{-1}$, respectively. For each parameter, the ratio of the values obtained at 75 and $20 \mu \mathrm{mol}$ photons $\mathrm{m}^{-2} \mathrm{~s}^{-1}-1$ was calculated (that is, the 0 line is equal to a $75 / 20$ ratio $=1$, which is equivalent to no change of values between light intensities). Significant changes between both light intensities are indicated with an asterisk. The values used for the 20 and the $75 \mu \mathrm{mol}$ photons $\mathrm{m}^{-2} \mathrm{~s}^{-1}$ conditions can be found in Supplementary Tables S3/S5 and S8/S9, respectively.

response. As the growth rate and photosynthetic characteristics (main pigments, $\mathrm{F}_{\mathrm{v}} / \mathrm{F}_{\mathrm{m}}, \alpha, \mathrm{E}_{\mathrm{k}}, \mathrm{rETR}_{\mathrm{m}}$ ) of the studied species were comparable between the growth forms at $20 \mu \mathrm{mol}$ photons $\mathrm{m}^{-2} \mathrm{~s}^{-1}$, we were able to compare their purely physiological light response.

Our study revealed a highly significant and pronounced difference in NPQ between the four growth forms. NPQ was significantly lower in EPL and TYCHO than in EPM species; differences in DES were only observed between EPL and other forms at lower light intensities. Within the EPM,

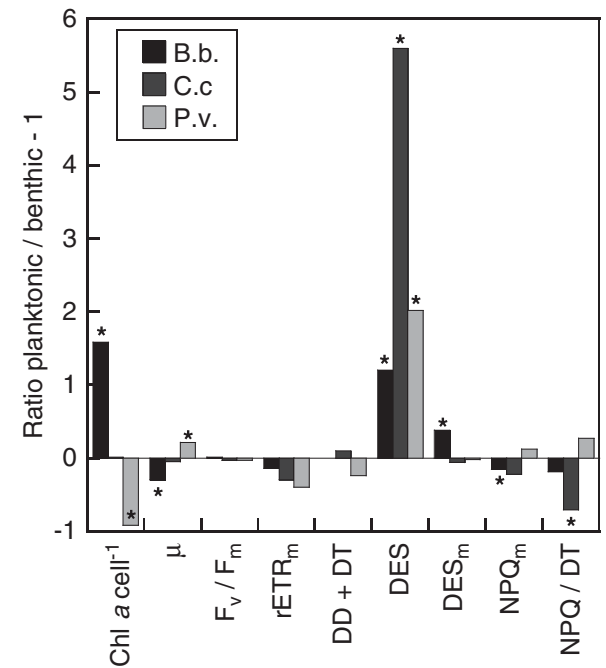

Figure 5 Comparison of growth, photosynthetic, pigment, NPQ of Chl fluorescence and XC parameters measured in the three tychoplankton (TYCHO) diatom species in 'benthic' and 'planktonic' conditions. For each parameter, the ratio of the values obtained under benthic and planktonic conditions -1 was calculated (that is, the 0 line is equal to a planktonic/benthic ratio $=1$, which is equivalent to no change of values between 'benthic' and 'planktonic' conditions). Chl $a$ per cell (in pg cell ${ }^{-1}$ ) and growth rates (in day ${ }^{-1}$ ) were measured on cells in exponential growth phase sampled $2 \mathrm{~h}$ after the onset of light; growth conditions were $20 \mu \mathrm{mol}$ photons $\mathrm{m}^{-2} \mathrm{~s}^{-1}$, 16-h light:8-h dark, $20^{\circ} \mathrm{C}$. Significant changes between both light intensities are indicated with an asterisk. The values used for the 'benthic' and 'planktonic' growth conditions can be found in Supplementary Tables S3/S5 and S10, respectively.

NPQ capacity was significantly higher in the nonmotile than in the motile forms. As all growth forms included both small and large species, the functional light response (NPQ capacity) apparently did not depend on biovolume or the Chl $a$ concentration per cell, as has also been observed in situ (Jesus et al., 2009). The absence of significant differences in PSII CET between growth forms underscores the importance of NPQ as the main fast photoprotective process in intertidal benthic 
diatoms, confirming earlier results for these organisms (Lavaud et al., 2002) but in contrast with planktonic diatoms (Lavaud et al., 2002, 2007). By analogy with previous studies on planktonic diatoms (Strzepek and Harrison, 2004; Lavaud et al., 2007; Dimier et al., 2009; Petrou et al., 2011; Lavaud and Lepetit, 2013), our data suggest that EPL and TYCHO diatoms are adapted to a less fluctuating light climate and/or to a lower average irradiance, and vice versa for EPM diatoms. This result fits well with the ecology of these growth forms. EPL is not only more abundant in muddy cohesive sediments where light penetration is more restricted than in sandy sediments (Paterson and Hagerthey 2001; Cartaxana et al., 2011), but, more importantly, their (micro-) migratory behaviour allows positioning at the optimal irradiance in the vertical light gradient and rapid escape from periodic excess light (Kromkamp et al., 1998; Conn et al., 2004; Consalvey et al., 2004; Serôdio et al., 2006). This alleviates the need to invest in a strong physiological capacity to respond to light stress as previously proposed (Jesus et al., 2009; Cartaxana et al., 2011), although the right balance between motility and physiology still remains essential (van Leeuwe et al., 2009; Perkins et al., 2010b; Cartaxana et al., 2011; Serôdio et al., 2012).

Such balance is more crucial in the EPM-M species, which can move but have only limited control over their immediate light environment as movement is restricted, usually within the sphere of individual sand grains. As expected, they showed a significantly lower NPQ and a higher $\mathrm{E} 50_{\mathrm{NPQ}}$ than EPM-NM, which have no behavioural control over their light environment. An alternative, but not exclusive, explanation could be related to the difference in exopolysaccharide (EPS) secretion between motile and non-motile growth forms. EPS secretion could work as an alternative electron sink under stressful conditions (that is, high light, nutrient limitation etc.) in order to limit the overreduction of the photosynthetic machinery ('overflow' hypothesis; Staats et al., 2000), alleviating the need for a strong NPQ. However, EPS secretion is not as fast as NPQ (minutes/hours vs seconds/ minutes) and may not be useful to the cells for responding to rapid light changes but only to cope with prolonged high light exposure. In addition, while the 'overflow' hypothesis is often proposed (Underwood and Paterson, 2003; Stal, 2009), it was never clearly proven. A few studies have shown a positive relationship between light intensity and EPS production (Underwood, 2002; Wolfstein and Stal, 2002) but other studies have reported a negative relation with light intensity and no relationship with nutrient limitation (Perkins et al., 2001; Hanlon et al., 2006). To date there is no information on EPS production in different benthic diatom growth forms, and only EPL species have been compared (Underwood and Paterson, 2003), showing no clear relationship between light response and EPS secretion. To our knowledge, there are no reports on a relationship between NPQXC capacity and EPS production. Finally, TYCHO typically alternates between resuspension in a highly turbid shallow water column at high tide and deposition and burial in the upper sediment layers of muddy sediments at low tide (deposition in sandy sediments does not occur because of the intense hydrodynamic disturbance in these sediments). As such, the TYCHO resembles planktonic diatoms adapted to subtle light fluctuations and/or on average low irradiance (Bailleul et al., 2010; Lavaud and Lepetit, 2013).

The reason for the NPQ differences between EPL and EPM can be explained by its main control: the $\mathrm{XC}$ dynamics. Previous in situ studies reported a consistently stronger DES under light stress in EPM than in EPL diatom communities (that is, in sandy vs muddy sediments) and related growth form with differential (behavioural vs physiological) photoregulatory strategies (Jesus et al., 2009; Cartaxana et al., 2011). As recently shown, a high NPQ is supported by the strong effective involvement of DT, which first depends both on a high DD + DT content and a high DES (Lavaud and Lepetit, 2013). The slope of the NPQ/DT relationship has been proposed as a good indicator of light climate adaptation: the higher the NPQ/DT slope, the better the adaptation to a highly fluctuating and/or on average high light climate (Dimier et al., 2009; Lavaud and Lepetit, 2013). All EPM species, and especially the nonmotile ones, showed XC parameter values, which are characteristic for a high NPQ capacity, viz. a higher DD + DT content and $\mathrm{DT}_{\mathrm{m}}$, which was $2 \times$ higher than in EPL. EPM-NM also tended to show a higher efficiency in promoting NPQ (NPQ/DT), but this difference was not significant because of high intra-group variability.

Within the EPM, NPQ is clearly more efficient in EPM-NM than EPM-M species. In EPM-M, the discrepancy between $\mathrm{E} 50_{\mathrm{NPO}}$ and $\mathrm{E}_{\mathrm{k}}$ is more pronounced than in non-motile forms: while there is no significant difference in $E_{k}$ between both growth forms, $\mathrm{E} 50_{\mathrm{NPQ}}$ is significantly higher in the motile growth forms. This suggests a weaker relationship between NPQ development and photochemistry in the latter group, with slower NPQ development with increasing E. Remarkably, E50 DT does not significantly differ between both growth forms, and the significantly higher initial induction of DT synthesis $\left(\mathrm{n}_{\mathrm{DT}}\right)$ but not NPQ $\left(\mathrm{n}_{\mathrm{NPQ}}\right)$ in the motile group, together with the fact that some representatives of this group show DT synthesis without NPQ, suggests that either DT is less or not involved in NPQ development, or that the light-dependent built-up of the transthylakoidal proton gradient (which is involved in both the activation of the DD de-epoxidase and the molecular control of NPQ) and the onset of NPQ are uncoupled (Lavaud et al., 2012; Lavaud and Lepetit, 2013). Our observations thus suggest that in contrast to the non-motile group, 
EPM-M species rely more on a behavioural response (motility) and/or involve DT in other photoprotective processes such as the prevention of lipid peroxidation by reactive oxygen species (Lepetit et al., 2010). The increase in $\mathrm{E} 50_{\mathrm{NPQ}}$ in the EPM-NM species Plagiogramma staurophorum during a shift to higher light illustrates the ability to physiologically modulate the NPQ vs E development kinetics to its light environment in contrast to EPM-M, EPL and TYCHO.

The influence of DT on the inter-group/species NPQ differences was further investigated by the acclimation to higher light $\left(75 \mu \mathrm{mol}\right.$ photons $\mathrm{m}^{-2} \mathrm{~s}^{-1}$, close to the mean $\mathrm{E}_{\mathrm{k}}$ for cells acclimated to $20 \mu \mathrm{mol}$ photons $\mathrm{m}^{-2} \mathrm{~s}^{-1}$ ). High light exposure is known to induce constitutive DT synthesis (Schumann et al., 2007) and in field conditions, DT is usually even present in significant amounts in cells adapted to low/moderate light (Jesus et al., 2009; van Leeuwe et al., 2009; Chevalier et al., 2010; Cartaxana et al., 2011). Acclimation to higher light resulted in a significant increase in XC pigments (DD + DT) and DES in most growth forms, suggesting that although EPL uses behavioural photoprotection, the XC is still important ( $c f$. above). $\mathrm{NPQ}_{\mathrm{m}}$ increased in most of the species examined, mainly because of a higher $\mathrm{DT}_{\mathrm{m}}$ resulting from a higher $\mathrm{DD}+\mathrm{DT}$ rather than a higher $\mathrm{DES}_{\mathrm{m}}$. The discrepancy between $\mathrm{DES}_{\mathrm{m}}$ and $\mathrm{NPQ}_{\mathrm{m}}$ as well as the low NPQ/DT may be due to the fact that the additional DT primarily served in the prevention of lipid peroxidation rather than in NPQ as previously reported in high light acclimated diatoms (see also above).

Although under low light conditions, the growth, photosynthetic and steady-state light-response features of TYCHO were similar to those of EPL diatoms (that is, low NPQ, $\mathrm{NPQ}_{\mathrm{m}}$ and $\mathrm{DT}_{\mathrm{m}}$ ), their dynamic light response was significantly different, that is, higher $E 50_{\mathrm{NPQ}}$. Surprisingly, $\mathrm{E} 50_{\mathrm{NPQ}}$ was beyond the natural light maximum $(2000-2500 \mu \mathrm{mol}$ photons $\mathrm{m}^{-2} \mathrm{~s}^{-1}$ ) illustrating the inability of TYCHO to strongly and/or continuously develop NPQ in the environmental high light range (a situation also encountered in one epipelic species: Navicula phyllepta). In contrast, its low $\mathrm{n}_{\mathrm{NPQ}}$ supported a relatively strong onset of NPQ at low Es. Both E50 ${ }_{\mathrm{DT}}$ and $\mathrm{n}_{\mathrm{DT}}$ were correspondingly high and low, respectively (and significantly different from EPL for $\mathrm{n}_{\mathrm{DT}}$ ), although $\mathrm{E} 5 \mathrm{D}_{\mathrm{DT}}$ was much lower than $\mathrm{E} 50_{\mathrm{NPQ}}$ suggesting a discrepancy between DT synthesis and NPQ development ( $c f$. above). The response of TYCHO to higher light was much more pronounced, with the strongest increase in XC pigments and DES of all growth forms. However, the $\mathrm{NPQ}_{\mathrm{m}}$ and $\mathrm{DT}_{\mathrm{m}}$ data (only available, however, for one representative species, Plagiogrammopsis vanheurckii) did not show a similar response, with $\mathrm{DT}_{\mathrm{m}}$ showing a more pronounced increase than $\mathrm{NPQ}_{\mathrm{m}}$, suggesting that NPQ development was low and that DT may have mainly been involved in other processes than NPQ. For most parameters, the response of the TYCHO species to growth in suspension ('planktonic' growth) was limited and largely species specific, except for a general increase in DES and a decrease (albeit just non-significant) in $\mathrm{rETR}_{\mathrm{m}}$. These data suggest that representatives of the TYCHO growth form are well adapted to their amphibious life style, which is characterized by an on average low irradiance (MacIntyre et al., 1996). In contrast, EPL species do not grow well in suspended, turbulent conditions (J Lavaud, personal observation).

Our study for the first time shows that intertidal benthic diatoms display growth form-specific variation in fast regulatory physiological mechanisms for photoprotective capacity (NPQ and the XC), which mirrors their behavioural light response. In EPL motile diatoms, exclusively belonging to the raphid pennate clade, the physiological response is not well developed, as these diatoms appear to largely rely on motility to control their immediate light environment. In the EPM-M, however, the physiological response remains essential because their movement is restricted to the sphere of individual sand grains. The evolution of the raphe system, the hallmark synapomorphy of the raphid pennate diatom clade, which enables locomotion, has therefore been essential for the colonization of intertidal sediments by not only migratory epipelic biofilms but also EPM-M. In contrast, NPQ and XC capacity is high in non-motile araphid pennate diatoms, which passively have to abide often pronounced variations in the intertidal light climate. TYCHO diatoms, which alternate between high tide resuspension in a turbulent and turbid water column, and low tide deposition in muddy sediments, appear to be adapted to an on average low light environment, with low NPQ and XC capacity.

Although we made no formal analysis of the relationship between functional and phylogenetic diversity, it is obvious that despite the fact that a behavioural photoprotective response (motility) is restricted to the raphid pennate diatom clade, differences in the studied physiological traits are more strongly driven by growth form than phylogenetic relatedness. For example, the EPM species Biremis lucens, despite being a raphid pennate species, has a non-motile growth form, and shows a NPQ capacity, which is more similar to EPM-NM than to the (phylogenetically more closely related) EPM-M and EPL. Similarly, photophysiological features of pennate raphid (Cylindrotheca closterium) and centric (Plagiogrammopsis vanheurckii and Brockmanniella brockmannii) TYCHO species were similar as reported before in planktonic centric/pennate species (Lavaud et al., 2004). Raphid pennate diatoms, which have colonized an epipsammic or tychoplanktonic niche, thus display a reverse evolutionary trade-off switch toward a much more performant physiological response. Our observations thus suggest that photoprotective capacity in diatoms is a highly adaptive trait, which is 
to a certain degree constrained by clade-specific evolutionary innovations (the evolution of the raphe system and hence a behavioural response) but also, and more importantly, by growth form, which ultimately defines the balance between the physiological and behavioural photoprotective response in these organisms. Such differential adaptation is of primary importance for the regulation of the photosynthetic productivity vs light, as has been demonstrated before in planktonic diatoms, where the photochemical vs the photoprotective energy allocation as a function of light is drastically different in species adapted to a fluctuating vs a more stable light environment (Wagner et al., 2006; Lavaud et al., 2007; Petrou et al., 2011; Lavaud and Lepetit, 2013). However, unlike in planktonic environments, the trade-off between a physiological and behavioural response in benthic diatoms allows local co-existence of different growth forms under the same overall light environment.

\section{Conflict of Interest}

The authors declare no conflict of interest.

\section{Acknowledgements}

The authors acknowledge the Centre National de la Recherche Scientifique-CNRS, the University of La Rochelle-ULR, the Contrat Plant Etat Région-CPER 'Littoral', the Region Poitou-Charentes, the Deutscher Akademischer Austausch Dienst-DAAD, the Research Foundation Flanders (FWO project G.0222.09N), Ghent University (BOF-GOA 01G01911) and the Egide/Campus France-PHC Tournesol ( ${ }^{\circ}$ 28992UA) exchange program for their financial support.

\section{References}

Admiraal W. (1984). The ecology of estuarine sediment inhabiting diatoms. Prog Phycol Res 3: 269-314.

Armbrust EV. (2009). The life of diatoms in the world's oceans. Nature 459: 185-192.

Bailleul B, Rogato A, de Martino A, Coesel S, Cardol P, Bowler C et al. (2010). An atypical member of the light-harvesting complex stress-related protein family modulates diatom responses to light. Proc Natl Acad Sci USA 107: 18214-18219.

Barton AD, Pershing AJ, Lichtman E, Record NR, Edwards KF, Finkel ZV et al. (2013). The biogeography of marine plankton traits. Ecol Lett 16: 522-534.

Brunet C, Lavaud J. (2010). Can the xanthophyll cycle help extract the essence of the microalgal functional response to a variable light environment? J Plankton Res 32: 1609-1617.

Cartaxana P, Ruivo M, Hubas C, Davidson I, Serôdio J, Jesus B. (2011). Physiological versus behavioral photoprotection in intertidal epipelic and epipsammic benthic diatom communities. J Exp Mar Biol Ecol 405: 120-127.
Chevalier EM, Gévaert F, Créach A. (2010). In situ photosynthetic activity and xanthophylls cycle development of undisturbed microphytobenthos in an intertidal mudflat. J Exp Mar Biol Ecol 385: 44-49.

Coelho H, Vieira S, Serôdio J. (2011). Endogenous versus environmental control of vertical migration by intertidal benthic microalgae. Eur $J$ Phycol 46: 271-281.

Conn SA, Bahena M, Davis JT, Ragland RL, Rauschenberg CD, Smith BJ. (2004). Characterisation of the diatom photophobic response to high irradiance. Diatom Res 19: $167-179$.

Consalvey M, Paterson DM, Underwood GJC. (2004). The ups and downs of life in a benthic biofilm: migration of benthic diatoms. Diatom Res 19: 181-202.

Depauw FA, Rogato A, d'Alcala MR, Falciatore A. (2012). Exploring the molecular basis of responses to light in marine diatoms. J Exp Bot 63: 1575-1591.

Dimier C, Corato F, Tramontano F, Brunet C. (2007). Photoprotective capacity as functional trait in planktonic algae: relationship between xanthophyll cycle and ecological characteristics in three diatoms. J Phycol 43: 937-947.

Dimier C, Giovanni S, Ferdinando T, Brunet C. (2009). Comparative ecophysiology of the xanthophyll cycle in six marine phytoplanktonic species. Protist 160: $397-411$.

Edwards KF, Litchman E, Klausmeier CA. (2013). Functional traits explain phytoplankton community structure and seasonal dynamics in a marine ecosystem. Ecol Lett 16: 56-63.

Eilers PHC, Peeters JCH. (1988). A model for the relationship between light intensity and the rate of photosynthesis in phytoplankton. Ecol Model 42: 199-215.

Goss R, Jakob T. (2010). Regulation and function of xanthophyll cycle-dependent photoprotection in algae. Photosynth Res 106: 103-122.

Gottschalk S, Kahlert M. (2012). Shifts in taxonomical and guild composition of littoral diatom assemblages along environmental gradients. Hydrobiologia 694: 41-56.

Hamels I, Sabbe K, Muylaert K, Barranguet C, Lucas C, Herman $\mathrm{P}$ et al. (1998). Organisation of microbenthic communities in intertidal estuarine flats, a case study from the Molenplaat (Westerschelde estuary, The Netherlands). Eur J Protistol 34: 308-320.

Hanlon ARM, Bellinger B, Haynes K, Xiao G, Hofmann TA, Gretz MR et al. (2006). Dynamics of extracellular polymeric substance (EPS) production and loss in an estuarine, diatom-dominated, microalgal biofilm over a tidal emersion-immersion period. Limnol Oceanogr 51: 79-93.

Haubois A-G, Sylvestre F, Guarini J-M, Richard P, Blanchard GF. (2005). Spatio-temporal structure of the epipelic diatom assemblage from an intertidal mudflat in Marennes-Oleron Bay, France. Est Coast Shelf Sci 64: 385-394.

Herlory O, Guarini J-M, Richard P, Blanchard GF. (2004). Microstructure of microphytobenthic biofilm and its spatio-temporal dynamics in an intertidal mudflat (Aiguillon Bay, France). Mar Ecol Prog Ser 282: 33-44.

Hillebrand C, Durselen CD, Kirschtel D, Pollingher U, Zohary T. (1999). Biovolume calculation for pelagic and benthic microalgae. J Phycol 35: 403-424.

Huisman J, Johansson AM, Folmer EO, Weissing FJ. (2001). Towards a solution of the plankton paradox: the importance of physiology and life history. Ecol Lett 4: 408-411. 
Jakob T, Goss R, Wilhelm C. (1999). Activation of diadinoxanthin de-epoxidase due to a chlororespiratory proton gradient in the dark in the diatom Phaeodactylum tricornutum. Plant Biol 1: 76-82.

Jeffrey SW, Humphrey GR. (1975). New spectrophotometric equations for determining chlorophylls a, b, c1 and c2 in higher plants, algae and natural phytoplankton. Biochem Physiol Pflanzen Bd 167: 191-194.

Jesus BM, Brotas V, Ribeiro L, Mendes CR, Cartaxana P, Paterson DM. (2009). Adaptations of microphytobenthos assemblages to sediment type and tidal position. Cont Shelf Res 29: 1624-1634.

Jørgensen E, Pedersen AR. (1998). How to obtain those nasty standard errors from transformed data-and why they should not be used. In 7 BRU-Ir (ed.) Danish Institute of Agricultural Sciences: Aarhus, Denmark, p 20.

Key T, McCarthy A, Campbell DA, Six C, Roy S, Finkel ZV. (2010). Cell size trade-offs govern light exploitation strategies in marine phytoplankton. Environ Microbiol 12: 95-104.

Kooistra WHCF, Gersonde R, Medlin LK, Mann DG. (2007). The origin and the evolution of the diatoms: their adaptation to a planktonic existence. In: Falkowski PG, Knoll AH (eds) Evolution of Primary Producers in the Sea. Elsevier Academic Press: Burlington, pp 207-249.

Kromkamp J, Barranguet C, Peene J. (1998). Determination of microphytobenthos PSII quantum efficiency and photosynthetic activity by means of variable chlorophyll fluorescence. Mar Ecol Prog Ser 162: 45-55.

Larson CA, Passy SI. (2012). Taxonomic and functional composition of the algal benthos exhibits similar successional trends in response to nutrient supply and current velocity. FEMS Microbiol ECol 80: 352-360.

Lavaud J. (2007). Fast regulation of photosynthesis in diatoms: mechanisms, evolution and ecophysiology. Funct Plant Sci Biotech 267: 267-287.

Lavaud J, Lepetit B. (2013). An explanation for the inter-species variability of the photoprotective nonphotochemical chlorophyll fluorescence quenching in diatoms. Biochim Biophys Acta 1827: 294-302.

Lavaud J, Materna AC, Sturm S, Vugrinec S, Kroth PG. (2012). Silencing of the violaxanthin de-epoxidase gene in the diatom Phaeodactylum tricornutum reduces diatoxanthin synthesis and non-photochemical quenching. PLoS One 7: e36806.

Lavaud J, Rousseau B, Etienne A-L. (2004). General features of photoprotection by energy dissipation in planktonic diatoms (Bacillariophyceae). J Phycol 40: 130-137.

Lavaud J, Strzepek RF, Kroth PG. (2007). Photoprotection capacity differs among diatoms: possible consequences on the spatial distribution of diatoms related to fluctuations in the underwater light climate. Limnol Oceanogr 52: 1188-1194.

Lavaud J, van Gorkom HJ, Etienne A-L. (2002). Photosystem II electron transfer cycle and chlororespiration in planktonic diatoms. Photosynth Res 74: 51-59.

Lepetit B, Goss R, Jakob T, Wilhelm C. (2012). Molecular dynamics of the diatom thylakoid membrane under different light conditions. Photosynth Res 111: 245-257.

Lepetit B, Volke D, Gilbert M, Wilhelm C, Goss R. (2010). Evidence for the existence of one antenna-associated, lipid-dissolved and two protein-bound pools of diadinoxanthin cycle pigments in diatoms. Plant Physiol 154: 1905-1920.
Litchman E, Klausmeier CA. (2008). Trait-based community ecology of phytoplankton. Ann Rev Ecol Evol Syst 39: 615-639.

MacIntyre HL, Geider JR, Miller DC. (1996). Microphytobenthos: the ecological role of the 'secret garden' of unvegetated, shallow-water marine habitats. I. Distribution, abundance and primary production. Estuaries 19: 186-201.

Mouget JL, Perkins R, Consalvey M, Lefebvre S. (2008). Migration or photoacclimation to prevent high irradiance and UV-B damage in marine microphytobenthic communities. Aquat Microb Ecol 52: 223-232.

Méléder V, Rincé Y, Barillé L, Gaudin P, Rosa P. (2007). Spatiotemporal changes in microphytobenthos assemblages in a macrotidal flat (Bourgneuf Bay, France). J Phycol 43: 1177-1190.

Paterson DM, Hagerthey SE. (2001). Microphytobenthos in contrasting coastal ecosystems: biology and dynamics. In: Reise K (ed.) Ecological Comparisons of Sedimentary Shores. Springer-Verlag: Berlin Heidelberg, pp 106-125.

Perkins RG, Kromkamp JC, Serôdio J, Lavaud J, Jesus BM, Mouget J-L et al. (2010a). The Application of variable chlorophyll fluorescence to microphytobenthic biofilms. In: Suggett DJ, Prášil O, Borowitzka MA (eds) Chlorophyll a Fluorescence in Aquatic Sciences: Methods and Applications. Springer: The Netherlands, pp 237-275.

Perkins RG, Lavaud J, Serôdio J, Mouget J-L, Cartaxana P, Rosa P et al. (2010b). Vertical cell movement is a primary response of intertidal benthic biofilms to increasing light dose. Mar Ecol Prog Ser 416: 93-103.

Perkins RG, Mouget J-L, Lefebvre S, Lavaud J. (2006). Light response curve methodology and possible implications in the application of chlorophyll fluorescence to benthic diatoms. Mar Biol 149: 703-712.

Perkins RG, Underwood GJC, Brotas V, Snow GC, Jesus B, Ribeiro L. (2001). Response of microphytobenthos to light: primary production and carbohydrate allocation over an emersion period. Mar Ecol Prog Ser 223: 101-112.

Petrou K, Doblin MA, Ralph PJ. (2011). Heterogeneity in the photoprotective capacity of three Antarctic diatoms during short-term changes in salinity and temperature. Mar Biol 158: 1029-1041.

Ribeiro L, Brotas V, Rincé Y, Jesus BM. (2013). Structure and diversity of intertidal benthic diatom assemblages in contrasting shores: a case study from the Tagus estuary. J Phycol 49: 258-270.

Roy S, Llewellyn CA, Skarstad Egeland E, Johnsen G. (2011). Phytoplankton Pigments-Characterization, Chemotaxonomy and Applications in Oceanography, Cambridge Environmental Chemistry Series. Cambridge University Press: Cambridge, UK, pp 845.

Sabbe K, Vanelslander B, Ribeiro L, Witkowski A, Muylaert K, Vyverman W. (2010). A new genus, Pierrecomperia gen. nov., a new species and two new combinations in the marine diatom family. Cymatosiraceae Vie et Milieu 60: 243-256.

Sabbe K, Witkowski A, Vyverman W. (1995). Taxonomy, morphology and ecology of Biremis lucens comb. nov. (Bacillariophyta): a brackish-marine, benthic diatom species comprising different morphological types. Bot Mar 38: 379-391.

Sabbe K. (1993). Short-term fluctuations in benthic diatom numbers on an intertidal sandflat in the Westerschelde estuary (Zeeland, The Netherlands). Hydrobiologia 269-270: 275-284. 
Saburova MA, Polikarpov IG. (2003). Diatom activity within soft sediments: behavioural and physiological processes. Mar Ecol Prog Ser 251: 115-126.

Schumann A, Goss R, Jakob T, Wilhelm C. (2007). Investigation of the quenching efficiency of diatoxanthin in cells of Phaeodactylum tricornutum (Bacillariophyceae) with different pool sizes of xanthophyll cycle pigments. Phycologia 46: 113-117.

Schwaderer AS, Yoshiyama K, de Tezanos Pinto P, Swenson NG, Klausmeier CA, Litchman E. (2011). Eco-evolutionary differences in light utilization traits and distributions of freshwater phytoplankton. Limnol Oceanogr 56: 589-598.

Serôdio J, Coelho H, Vieira S, Cruz S. (2006). Microphytobenthos vertical migratory photoresponse as characterised by light-response curves of surface biomass. Est Coast Shelf Sci 68: 547-556.

Serôdio J, Cruz S, Vieira S, Brotas V. (2005). Nonphotochemical quenching of chlorophyll fluorescence and operation of the xanthophyll cycle in estuarine microphytobenthos. J Exp Mar Biol Ecol 326: 157-169.

Serôdio J, Ezequiel J, Barnett A, Mouget J-L, Méléder V, Laviale $\mathrm{M}$ et al. (2012). Efficiency of photoprotection in microphytobenthos: role of vertical migration and the xanthophyll cycle against photoinhibition. Aquat Microb Ecol 67: 161-175.

Serôdio J, Lavaud J. (2011). A model for describing the light response of the nonphotochemical quenching of chlorophyll fluorescence. Photosynth Res 108: 61-76.

Serôdio J, Vieira S, Cruz S. (2008). Photosynthetic activity, photoprotection and photoinhibition in intertidal microphytobenthos as studied in situ using variable chlorophyll fluorescence. Cont Shelf Res 28: 1363-1375.

Staats N, Stal LJ, de Winder B, Mur LR. (2000). Oxygenic photosynthesis as driving process in exopolysaccharide production in benthic diatoms. Mar Ecol Prog Ser 193: 261-269.

Stal LJ. (2009). Microphytobenthos as a biogeomorphological force in intertidal sediment stabilization. Ecol Eng 36: 236-245.

Strzepek RF, Harrison PJ. (2004). Photosynthetic architecture differs in coastal and oceanic diatoms. Nature 431: 689-692.

Underwood GJC. (2002). Adaptation of tropical marine microphytobenthic assemblages along a gradient for light and nutrient availability in Suva Lagoon, Fidji. Eur J Phycol 37: 449-462.

Underwood GJC, Kromkamp J. (1999). Primary production by phytoplankton and microphytobenthos in estuaries. In: Nedwell DB, Raffaelli DG (eds) Adv Ecol Res, Vol 29. Academic Press, Elsevier: Waltham, MA, USA, pp 93-153.

Underwood GJC, Paterson DM. (2003). The importance of extracellular carbohydrate production by marine epiplelic diatoms. Adv Bot Res 40: 183-240.

van Leeuwe MA, Brotas V, Consalvey M, Forster RM, Gillespie D, Jesus B et al. (2009). Photacclimation in microphytobenthos and the role of the xanthophylls pigments. Eur J Phycol 43: 123-132.

Wagner H, Jakob T, Wilhelm C. (2006). Balancing the energy flow from captured light to biomass under fluctuating light conditions. New Phytol 169: 95-108.

Wolfstein K, Stal LJ. (2002). Production of extracellular polymeric substances (EPS) by benthic diatoms: effect of irradiance and temperature. Mar Ecol Prog Ser 236: 13-22.

Wu H, Roy S, Alami M, Green BR, Campbell AD. (2012). Photosystem II photoinactivation, repair, and protection in marine centric diatoms. Plant Physiol 160: 464-476.

Supplementary Information accompanies this paper on The ISME Journal website (http://www.nature.com/ismej) 